\title{
EUTHANASIA AND (D)EVOLUTION IN SPECULATIVE FICTION
}

\author{
By Nancee Reeves
}

IN THE LATTER PART OF THE nineteenth century future or speculative fiction became big business in Britain. It was a safe haven for invasion narratives, for socialist paradises or hells, for worlds ruled by benevolent machines, or worlds ruined by mechanical dependence. Themes and plots were varied, but they always reflected some facet of contemporary society. The future was not a bubble, untouched by time or trouble, but a field of battle, where ideas could be tested and philosophies given a test drive. The future was a place where the mistakes or triumphs of today dictated the course of human progress. I argue in this essay that the nascent ideas about euthanasia of the early and middle Victorian period became full-fledged philosophies in the late-Victorian period and that Malthusian philosophy and Darwinian-informed theories were manipulated by novelist and theorist-turned- novelists, resulting in euthanasia becoming a tool in class warfare and in the fight to eradicate social undesirables for their good and for the good of society.

While some speculative fiction has strong plots and well-drawn characters, a striking facet of the genre is rambling narratives with little or no action. Speculative fiction was often, but not always, nothing more than philosophy spread over a weak narrative frame. This was, in part, because lay scientists saw fiction as a powerful vehicle in communicating their ideas to a wide readership and they did not always have the skills or the inclination to wed their ideas with their plots. Fiction was less an art form and more a tool that could be shaped to convey their interpretation of biological research. By making use of plot, characterization, and setting, apparatuses unique to fiction, authors were able to write social commentary that would have the commercial appeal and reach of fiction and protect them from moral backlash. How could readers protest events and ideas thousands of years distant from the present? The future provided freedom of thought and expression. Among the most controversial and popular of the ideas explored in this genre are three theories that came, in the hands of lateVictorian writers, to be linked: evolution, devolution, and euthanasia. By stressing man's obligation/willingness to take an active part in their evolutionary advancement, speculative writers caused euthanasia to be seen as a part of humanity's inevitable evolution toward a more advanced state of being, or to symbolize a regression to a darker, more savage time. By looking at examples of late-Victorian speculative fiction in which euthanasia is an important component of advanced utopic or dystopic society, it becomes clear that, through the efforts of theorists with active social agendas, evolution and euthanasia became linked. This link has its 
basis not only in natural selection, but also in the social Darwinism that permeated Victorian social norms and in the late-Victorian interest in eugenics, a middle-class movement that found fault in the perceived indolence of the upper class and the degeneracy of the lower class. In addition, the much lauded Victorian value of self-reliance allowed euthanasia to be paired with self-sacrifice and altruism, turning a rather brutal theory into a uniquely Victorian virtue. Fiction allowed social theorists to cajole, encourage, inspire or warn their readers, and the language of evolution gave them the illusion of scientific authority.

According to N. D. A. Kemp in his study of the British euthanasia movement there is a dearth of empirical data on the rise of euthanasia because of its "illicit" nature - it was illegal and as such no one would admit to practicing it. Because of this scholars looking to study why euthanasia became a popular philosophical idea in the nineteenth century look to abstract arguments in science journals, law journals, and theological and medical debates. Even with these resources, the lack of research on the British euthanasia movement is surprising. Most studies focus on the Nazi euthanasia programs and America's "fitter family" movement. Kemp's Merciful Release: The History of the British Euthanasia Movement (2002) is the only comprehensive analysis of this subject. I propose to expand the study of euthanasia by moving beyond non-fiction sources. By looking at speculative fiction it is possible to see in action the main causes, already identified by medical and history scholars, for the growing interest in euthanasia: the decline of Evangelicalism, the rise of medical science, and the Victorian veneration of self-reliance and civic duty. The way these elements play out in fiction make clear what types of people were labeled expendable and how their persecution was being vindicated.

I begin with a reading of Samuel D. Williams's essay, "Euthanasia" (1870), the first public call for active euthanasia. I will pay special attention to the Darwinian language that shows how Williams linked his theory of euthanasia with that of human advancement. I will also show how the historical context of the essay was informed by Darwinism and social Darwinism, how response to the essay reinforced these ideas, and how all these ideas converged with eugenic theory, a movement that started in the late-Victorian period and peaked at the turn of the century. It is no coincidence that all these factors came together during the same time period, or that speculative fiction became a literary force during that time. To show how one idea fed off the other, and to illustrate the direct line between early-Malthusian ideas, Darwinian theories, and the presence of late-Victorian euthanasia in speculative fiction, I will review the main speculative-fiction euthanasia texts of the period, showing how Malthusian class theory, fueled by the Victorian value of self-reliance, become entwined with evolution and euthanasia. I will finish with a close reading of Anthony Trollope's The Fixed Period (1882), a speculative fiction novel that revolves around the forced euthanization of a socially undesirable class. ${ }^{1}$

\section{Theories of Euthanasia, Darwinism, and Eugenics}

EUTHANASIA THOUGHT HAD TWO MAIN strains in the Victorian period: social pressure that arose from such legislation as the New Poor Law, and the impact of Darwinian thought in the mid- to late-nineteenth century. Many of the ideas behind the New Poor Law would be categorized today as social Darwinism, as would other popular Victorian terms such as free-market political economy and enlightened self-interest, which were bandied about in the middle- and upper-class as justifications for the exploitation and negligence of the 
working class, and, for those with a religious bent, it was possible to argue that lower classes needed to be kept poor so they would be virtuous. Despite the name, social Darwinism and Darwinism have no intrinsic relation. The ideas we associated with social Darwinism were already strong and viable theories in the pre-Darwinian days of the early Victorian period and it is today accepted that social Darwinism is not a logical consequence of Darwinism. However, in 1859, with the publication of The Origin of Species, natural selection and the struggle for existence became the main philosophy needed to justify laissez-faire economic and social policies. Politicians, economists, social critics, and industrialists, among others, used Darwin's theories and the theories of evolutionist before him - which were intended to apply only to the natural world over the course of thousands of years - to give sanction to policies that seemed to be designed to weed out the weak and useless. The New Poor Law, a series of laws that largely absolved the rich of the responsibility of taking care of the poor all in the name of making the poor better, more self-sufficient citizens, was one such policy. The American industrialist John D. Rockefeller exemplified to what extent social Darwinism was seen as not just a justification for social negligence, but also an actual law of God and nature that could not be refuted, when he told a Sunday-school class that "the growth of a large business is merely a survival of the fittest.... The American Beauty rose can be produced in the splendor and fragrance which bring cheer to the beholder only by sacrificing the early buds which grow up around it. This is not an evil tendency in business. It is merely the working-out of a law of nature and God" (qtd. in Ghent 29). According to one nineteenth-century economist, the laws of natural selection were "merely God's regular methods of expressing his choice and approval" (qtd. in Appleman 11). Social Darwinism was the one outcropping of natural selection on which both secular and non-secular thinkers could agree.

Herbert Spencer, who, rather unfairly, is today considered the father of social Darwinism, and the man who coined the phrase "survival of the fittest," was highly influenced by Malthus's An Essay on the Principle of Population (printed 1798, revised 1826), as was Darwin. In this essay Malthus predicted Britain's population problem and laid the blame squarely on the shoulders of poor but fertile British women. According to Malthus, population growth was outstripping man's ability to feed everyone and hence was hindering man's move toward a utopian society. Malthus argued that nature should be allowed to take its course; starvation and famine should be allowed to weed out the poor. He was against the Old Poor Law and any mandatory assistance that sustained the less fortunate. In addition, he recommended that the poor should not be allowed to marry or reproduce. Malthus's view of how society should treat the poor, and children in particular, can be seen in this notorious passage that appeared in the second edition of An Essay:

\footnotetext{
A man who is born into the world already possessed, if he cannot get subsistence from his parents on whom he has a just demand, and if the society do not want his labor, has no claim of right to the smallest portion of food, and, in fact, has no business to be where he is. At nature's mighty feast there is no vacant cover for him. She tells him to be gone, and will quickly execute her own orders, if he do not work upon the compassion of some of her guests. If these guests get up and make room for him, other intruders immediately appear demanding the same favor.... The guest[s] learn too late their error, in counteracting those strict orders to all intruders, issued by the great mistress of the feast, who, wishing that all her guests should have plenty, and knowing that she could not provide for unlimited numbers, humanely refused to admit fresh comers when her table was already full. (127-28)
} 
This passage, which was so controversial that it was cut from later editions of the essay, seems to say that compassion is harmful, as there will never be enough for everyone and giving to the poor means depriving the more fortunate, and that the poor are the cause, and not just the victims, of poverty. While Malthus was making an important point about population control, some of his more fervent opponents, such as William Godwin and Jean-Jacque Rousseau, were loath to address, the complexity of his argument was often forgotten in favor of the sensationalism of such passages as quoted above.

Spencer and many others saw social Darwinism as a continuation of Malthus's ideas and as scientific proof that providing aid to the weak was a fruitless and unnatural act that would eventually weaken society as a whole. While this is a simplification of Spencer's philosophy and ignores the majority of his ideas, it is the part of First Principles of a New System of Philosophy (1862) that the public, both in his time and today, latched onto. Eventually, in more radical circles, this theory came to include the idea of discouraging the breeding of "useless" members of humanity both for their own and society's good. This argument led to Francis Galton's theory of eugenics, particularly negative eugenics, and culminated in Dr. C. E. Goddard's call for non-voluntary mercy killing. Goddard's theories, which will be explored later, were extreme for his time and were largely unsupported even by die-hard eugenicists. Not until World War II and the rise of the Nazi party was Goddard's more extreme brand of eugenics put into practice, and in a way he would never have been able to anticipate.

Although most Victorians were not as extreme as Goddard, Spencer's ideas, though inviting criticism, were widely accepted. This is understandable, as they were nothing more than a plain statement of the Victorian ideal of self-reliance that had dominated the political and social sphere for years. People who violated the social contract, such as fallen women, or who could not take care of themselves, such as bastard children, were undoubtedly the weak and, as a matter of God, nature, and science, would be eliminated one way or another. The rhetoric of many social reformers, novelists, politicians, and church leaders intimated that this branch of society would be better off dead. But these earlier Victorians stopped short of actually suggesting they be killed. The publication of Williams's "Euthanasia" in 1870 was the first time in the Victorian world that a paper was published that expressed this exact sentiment. While Williams focuses on medical patients in agony, rather than social outcasts, his ideas are clearly applicable to those deemed socially unfit. We can see in this essay not only social Darwinism at work but also the origins of a small body of late-century speculative literature that focuses on politicized mercy killings. This essay, the debates that came from it, and the following speculative literature were, I argue, a natural result of a society in which death for ailing and unproductive members was an acceptable, if regrettable, alternative.

Euthanasia, in the modern sense of the word, first became a topic for debate in the post-classical world in 1870, when Williams's essay "Euthanasia" was published as part of the Birmingham Speculative Club's essay series. This essay was the first to use the term euthanasia to mean justifiable mercy-killing, rather than a good, peaceful death. Indeed, for many years after Williams's essay, euthanasia retained its older, classical meaning as well as its new, more controversial definition. "Euthanasia" was part of a small printing, but because of its sensational nature, it was reviewed by a series of popular papers, thus making its contents common knowledge for readers interested in such philosophical debate. Williams's essay became the catalyst for the physician-assisted euthanasia debates that still rage today. Williams's main argument - that it should be the duty of medical attendants to 
provide an easeful death to all people suffering from "hopeless and painful illness" - would not have been possible without the advent of a number of medical advances: Frederick Setürner's isolation of morphine from opium in 1816, the development of ether as a surgical anesthetic in the 1840s, James Young Simpson's discovery of the anesthetic properties of chloroform in 1847, and Alexander Wood's development of the hypodermic syringe in 1855. The development of euthanasia as a viable medical concept, and not just a purely rhetorical argument, is thus tied to human advancement and human evolution. As society developed new ways to suppress pain and extend life, so too did it, debatably, grow past the animal need to live purely for the sake of living.

Williams's argument is well reasoned and well argued. He begins by calling attention to other medical innovations that were once viewed as radical but are now commonplace. This, he reasons, is the future of medically-assisted euthanasia. To attain this future, however, man must first realize the folly of the four main points of view used to argue against the practice: the sacredness of life, the cowardice of suicide, submission to the will of God, and the importance of "not quitting one's post, except at the bidding of one's commander" (214). Williams's main rhetorical technique is to point out how these four tenets are daily broken for selfish reasons, and hence their application to the discussion of medically assisted euthanasia is both hypocritical and misplaced. For example, Williams argues that man is constantly working to make his life more comfortable, which shows that he is not willing to submit to the will of God if it means forgoing luxuries such as running water. Indeed, according to Williams, submitting to the will of God has no meaning beyond the idea that if you cannot escape suffering then you must suffer "uncomplainingly" what must be borne. But as man has the ability to ease the pain of death and hence there is no will of God to which to submit (218). Williams continues in this vein, dismantling each of the main arguments he believes will be brought against him. There is no doubt of his humanitarian and compassionate aims. Overall, he paints an eloquent picture of man forced "to suffer for mere suffering's sake" (218) and for the caprice of other men's moral objections, which can mean nothing in the face of such torture.

However, mercy for the victim, while constituting Williams's main argument, is not his only argument. He also concerns himself with the survivors - the social grouping, so to speak. Early in his essay, Williams addresses the suffering of the friends and family of the dying person, who are forced "to stand by in helpless misery" (212). This by itself is a mild reminder to the doctor that more people than just the patient are suffering, but he then makes this same appeal to the dying person: "Those who feel sure of themselves even before torment [need to consider] if it be not a man's duty to consider others' feelings, and to weigh others' endurance as well as his own; and to bethink himself whether he ought to condemn those nearest him to witness suffering which they would find it almost as easy to bear themselves as to see another bear" (220). A burden of guilt is now placed on the dying man, and he is asked to give up his life early, even though he can endure the pain, for the feelings of others.

Williams then moves from consideration for the feelings of others to the burden the patient presents to society. According to Williams, euthanasia is justifiable not only because of the pain of the individual, but also because "his life can no longer be of use to others" (213), a theme to which he returns repeatedly. The consideration of a life's "use value" changes the essay's focus from quality-of-life issues to the concept of "comparative social worth," making them byproducts of social Darwinism. ${ }^{2}$ To be fair, Williams is merely anticipating arguments 
that he suspects will be made against euthanasia; however, the fact that he broaches issues of social utility betrays a utilitarian view of life. Such issues are often raised in euthanasia fiction to justify both voluntary and non-voluntary mercy-killing

Theories of evolution and natural selection play a large part in "Euthanasia." The essay opens by singing the benefits of chloroform, "one of the very greatest practical benefits which science has hitherto conferred on mankind" (210). While such evidence of man's applied scientific progress is not what Darwin had in mind when he wrote of evolution, it was how such innovation was popularly viewed. Williams then makes a very well-reasoned argument about how the public (especially the man of science) was once against the use of chloroform to ease the pain of childbirth because it showed "impatience with the ways of Providence" (210), but now approves it. While Williams is clearly setting up a parallel between earlier protests over using chloroform during childbirth and the protests that are surely to greet his proposal, he is also speaking of all scientific discoveries: man may riot against "ungodly" innovation, but logic will overcome. His faith in humanity, and in his own proposition, is touching, if naïve.

Williams extols man's use of applied science throughout the essay, citing it as evidence of "man's genius" (220), but his greatest engagement with natural selection is in his evident fear and resentment toward nature. In Darwin Among the Poets, Lionel Stevenson states that, when it came to natural selection, "the most painful element to the poetic mind was the revelation of cruelty in nature" (45). Just as the poets had to give up their idea of nature as beneficent and become acclimated to it as "red in tooth and claw" (a line Williams quotes in his essay), so did Williams shatter the idea that a natural death would be one of ease and beauty. The perfect Victorian death was one in which the dying person lingered long enough to say goodbye to family and friends and was allowed time to become purified by the dying process and make peace with God. ${ }^{3}$ Novels and periodicals of the time were full of sentimental passages and images of dying people gracefully reposed in bed, surrounded by their weeping relatives. Williams gives readers a very different picture:

\footnotetext{
[Loved ones must] stand by in helpless misery, while one near to them was being done to death by the hideous tortures of a lingering disease ... the patient, all this weary while, getting no respite from fierce pain, except in the brief intervals of feverish broken sleep: who have had to witness all this, with the full knowledge, too, that the patient knew his fate as well as the watcher did: knew that there was no hope of relief but in death, and that death was to be reached only by the gradual exhaustion of the bodily strength; with the knowledge, too, that the last living moments would probably be the hardest to bear of all, and might possibly culminate in almost unimaginable horror. (212-13)
}

Williams makes clear this scene is the fault of and result of Nature, left to her own devices: "death by disease is always death by torture; and the wit of man has never devised torture more cruel than are some of Nature's methods of putting her victims to death. All the talk about the kindness of Nature, 'the mighty mother,' is rhodomontade which no rational being could be guilty of if he looked facts straight in the face, and spoke only according to what he saw. 'Our mother' Nature may be, and mighty she may be, but kind most assuredly she is not" (224). To Williams euthanasia is a weapon in the fight against nature, that "dread power," full of "rapine and cruelty and lust" (226) to which "a man's life ... is of no more value than a bird's" (214). Only by using his wits can man outfox nature and snatch her 
intended prey out from under her nose - a quick, easy death is man's greatest defiance of and defense against nature.

There is no question that the nature Williams hopes to defy is that same force Darwin writes of in The Origin of Species, even if he does mix Darwin's science with the social science of Spencer. Fully half of "Euthanasia" is taken up by a bleak analysis of the hopelessness of man's position, couched in language and imagery taken directly from Darwin's writings. According to Williams, nature intends for "the weak to go to the wall, and for "the vigour of the race' to be maintained" (229), but man has the means to outwit nature, not by escaping death, but by anticipating it and dying on his own terms. Williams's view on euthanasia and nature can best be summed up with his rather poetic line: "After all is said that can be said, human life remains but a sorrowful thing at best, and a real alleviation of its pain is the greatest service which man can render to man" (231). If the weak must "go to the wall," there is no reason they cannot go in comfort.

Thus, Williams argues that natural selection is inescapable and that the best man can do is to free weaker members of society from its greatest ravage - a slow, painful death - while also arguing the social Darwinist idea that once a person is no longer a useful member of society, his best option is to take himself out of it. According to Kemp, "While we should be wary of depicting Darwin as the man responsible for ushering in a secular age we should be similarly cautious of underestimating the importance of evolutionary thought in relation to the questioning of the sanctity of human life" (19). Williams's Darwinian-based arguments are clearly strong evidence of Kemp's statement. The conflation of scientific and social Darwinism distorts what is essentially a rational, medical argument into a creed about the hopelessness of the human condition. This idea is the basis of all dystopian/utopian literature that includes euthanasia, and it is no accident that the majority of such literature came after the publication of Williams's essay and the highly visible argument that followed.

Williams's essay was reviewed in yhe Saturday Review soon after its publication, bringing the essay to the public eye and sparking a flurry of responses in various periodicals. The majority of letter writers were against Williams, but perhaps not for the reasons anticipated. An editorial in the Spectator sums up the most common objection to Williams's proposal: it put too much responsibility on the medical man and on the patient. It was felt that semantics bogged down Williams's argument, for who was to decide when a malady was "incurable"? The Hippocratic Oath and Judeo-Christian ideas were secondary to this worldly, but valid, concern. "Euthanasia" was reprinted four times in the three years after its publication, with each successive reprinting resulting in a flurry of letters and editorials (Kemp 12-16). However, the arguments against Williams, which have a predictable sameness to them, are not as interesting as the support put forward by critics, scholars and social reformers who agreed with and built their own ideas on Williams's work.

If Williams's argument for mercy-killing was largely concerned with the well-being of the sufferer, other arguments made clear the benefit to society. One year after "Euthanasia" was published, Lionel Tollemache suggested that euthanasia could be used to counterbalance modern medicine, which was working against the interests of natural selection, using as his example the "idle or frivolous man or woman," probably a "drunkard" (17-18). He also tacitly endorsed death for useless members of society when he compared them unfavorably to suicides, who may deprive society of their services, but who are at least not the "living burden" of an idler (16). Two years later, noted birth control campaigner Annie Besant wrote an essay, also called "Euthanasia," in which she states that suicide is selfish in most cases, 
as it deprives society of that person's services. However, if the potential suicide is aware that he is no longer useful to society, it is his duty to relieve society of "a useless burden" (qtd. in Kemp 156). Numerous articles and letters were published in this vein, running the gambit from historical (naming past cultures that killed off their old and infirm) to sociological (euthanizing the mentally insane). However, the one point all these writings had in common was that euthanasia could not be forced on anyone; it must be an individual choice.

Eventually, this battle was acknowledged by medical practitioners. In 1901, Dr. C. E. Goddard, who was influenced by the social Darwinian tone of Williams and Tollemache's writings, as well as the teachings of eugenics, became the first medical man to advocate for euthanasia. He lobbied for the voluntary euthanasia of the terminally ill and, quite unusually, the involuntary euthanasia of the mentally defective. While Goddard was the first medical man to show openly his support for euthanasia, many doctors were suspected of euthanizing patients, either out of kindness or convenience. An 1863 letter to the Spectator for example addressed the " "widespread' view among the laboring class that some hospital patients who suffered from advanced stages of syphilis and "hydrophobic disease" were "systematically suffocated to get them out of the way" (qtd. in Kemp 29). While such actions were periodically attributed to supporters of eugenics, the actual ideas behind this movement were more subdued. Supporters of eugenics usually fell into two camps: positive and negative. ${ }^{4}$ Advocates of positive eugenics encouraged fertility among what they saw as the gifted minority. Followers of negative eugenics wanted to restrict reproduction by undesirables, which included Goddard's mental defectives and, most interesting, casual laborers, the unskilled working class, slum-dwellers, and alcoholics (Barker 199). While eugenicists like Arnold White might advocate "sterilization of the unfit," very few openly backed outright euthanasia; Goddard was unique in this regard.

While Goddard's radical views were frowned upon, the direct line between earlyVictorian Malthusians, mid-Victorian social Darwinists, and late-Victorian eugenicists can be seen in these groups' overlapping views on social undesirables. In contemporary society, we tend to see eugenics as a racial issue. However, in the nineteenth and early twentieth century, eugenics was primarily a discourse on class, driven by the largest and most powerful class, the middle class (Richardson xvii). Like Darwinism and social Darwinism, eugenics was heavily influenced by the teachings of Malthus, specifically with the ideas that those of the lower class should not be allowed to reproduce and that charity impeded nature from taking its course. Eugenicists were against poor laws, even such emaciated ones that proliferated after 1834 under the guidance of Malthusians. In the eugenic view, such charity allowed undesirables to linger on much longer than they normally would, which was a disservice to both the poor and society. Empathy and charity resulted in long-term suffering. Social Darwinists viewed the poor laws as a drain on the strong for the benefit of the weak, which went against nature. While social Darwinism was a justification of the betterment of the strong with no regard to the weak, eugenics was regarded, at least by its proponents, as a philosophy of kindness, a "biological alternative to social charity" (Richardson 65). Eugenicists saw social reformers who wanted to strengthen the poor laws as misguided and harmful. W. R. Greg spoke for the majority of eugenicists when he implied that charity would result in a national disaster:

We have kept alive those who, in a more natural and less advanced state, would have died - and who, looking at the physical perfection of the race alone, had better have been left to die... In a wild state, 
by the laws of natural selection, only, or chiefly, the sounder and stronger specimens were allowed to continue their species; with us, thousands with tainted constitutions, with frames weakened by malady or waste, with brains bearing subtle and hereditary mischief in their recesses, are suffered to transmit their terrible inheritance of evil to other generations, and to spread it through the whole community. (359)

Greg's rhetoric is typical of eugenics, filled as it is with Darwinian imagery, and while he does not advocate murder, he states that certain people, in this case those who take charity from the state, are better off dead. It is also not always clear where the boundaries begin and end when it comes to "tainted constitutions." According to Angelique Richardson, "in the hereditarian climate of 1890 s, poverty, immorality, crime, and prostitution were all swept up under the umbrella of disease" (72). The language of sickness came to cover anything undesirable. Whatever their motives, all three groups, which often overlapped, used language and promoted laws or the repeal of laws that resulted in the passive euthanasia of those most dependent on society. This passive euthanasia occasionally broke out into active euthanasia, as shown with Williams and Goddard. It seems clear that Malthusians, social Darwinists, and eugenicists were waging an unacknowledged war on the lower class, an agenda that was recognized in speculative fiction.

\section{The Haves and the Have Nots: A Review}

IDEAS OF EUTHANASIA HAVE BEEN a part of speculative literature since Plato's Republic, where only the best specimens were allowed to breed with each other, and illegitimate and unsanctioned children were euthanized. The preponderance of such literature rose drastically throughout the nineteenth century, and, according to literary science critic Peter Morton, "most of the Utopian writing after 1870" had eugenics as a component (129). Anthony Trollope's The Fixed Period is unique as it is a work of future fiction in which euthanasia is not just a component, but the main issue. However, before offering a reading of this little-know novel by a well-known writer, one needs to look at the most important utopian/dystopian stories and novels to treat the topic so as to properly contextualize Trollope's novel and to show the climate in which the novel was written. While the following novels and stories take different approaches to euthanasia, in each case we again see euthanasia marking areas of social progression and raising questions about what we owe to society and to our fellow man. The use of euthanasia in speculative fiction was ubiquitous and varied, and yet its appearance always harkens back to the Malthusian theories of the early-Victorian era and connects those ideas to later eugenics thinking. Class politics is the driving point behind all these narratives. Whether from the viewpoint of "superior" men who are defending their world from degeneration, or an underclass trying desperately to survive, the battle is always between the haves and the have-nots. The evolution of euthanasia from a passive, little-voiced construct to a vital part of man's possible futures is apparent in the evolution of speculative fiction. It is also clear from the review below how the changing face of Victorian society, one that no longer unquestionably accepted all tenets of religion and instead mixed their faith with a belief in and a fear of science, is a key component of fiction, as is the idea that people will sacrifice or be sacrificed for the greater good.

In the majority of late-Victorian future fiction, euthanasia is merely implied. For example, in William Morris's socialist paradise, chronicled in News from Nowhere (1890), the narrator 
frequently refers to how beautiful all the people of Nowhere are: "I could hardly have believed that there could be so many good-looking people in any civilized country" (65). However, as people in Nowhere are allowed to breed with whomever they choose, a population of beautiful people could be achieved only through liberal use of eugenics, separation of undesirables from the main community (as is practiced in Galton's eugenic utopia Kantsaywhere, written in 1910), or euthanasia. The later revelation that certain hereditary diseases have disappeared supports this idea. A later novel by Morris, The Wood Beyond the World (1894), makes the benefits of eugenics-based euthanasia clear. After many adventures, the hero of The Wood comes to a city where the inhabitants take for their king the next foreigner who arrives after the death of their previous king, as long as he is "goodly" enough. He is paraded nude through the city and, if he is indeed strong and good-looking, he becomes king. But if he is "ill-fashioned and counterfeit," he is immediately strangled. This custom, which has been in practice for thousands of years, has resulted in a strong city, and at the novel's end, this eugenics policy is still practiced, unquestioned, by the current king. The late nineteenth century is full of eugenic utopias like News from Nowhere, Samuel Butler's Erewhon: or, Over the Range (1872); A Thousand Years Hence (1882) by "Nunsowe Green"; Edward Bellamy's Looking Backward (1888); and Walter Browne's 2894, or The Fossil Man (1894), the majority of which skirt the unpleasant side of a genetically pure society. In all these utopias there is no underclass or any citizens with undesirable social or genetic characteristics. The methods used to produce "pure societies" are never discussed, just the results. These are societies where everyone is self-reliant and civic duty is a religion.

A novel that takes civic duty to an extreme, Edward Bulwer-Lytton's The Coming Race (1871) was at the vanguard of Darwinian-influenced future fiction with its depiction of the evolutionarily superior Virl-ya race, with their hairless bodies, ${ }^{5}$ extra, tapered fingers, and their superior moral and intellectual understanding. In the last pages of the novel, the hero finds himself about to be euthanized so he will be unable to breed with a female Virl-ya and so contaminate the gene pool. The hero is naturally appalled, but to the Virl-ya, "it is no crime to slay those who threaten the good of the community; it would be a crime to slay the smallest insect that cannot harm us" (163). The Virl-ya had evolved to a point where they killed only to protect the race, consequently leaving much of their humanity behind them. Bulwer-Lytton's final analysis of the Virl-ya is unclear, as there is both much to admire and to fear in this evolved race.

This confusion or ambiguity about morals verses civic duty is common in speculative fiction, especially that of H. G. Wells. Wells's novels in general are full of degeneration, social Darwinism, eugenics, and even, on an individual level, mercy killing, such as Edward's shooting of the Leopard Man in The Island of Doctor Moreau. However, When the Sleeper Wakes (1899) and Anticipations of the Reactions of Mechanical and Scientific Progress upon Human Life and Thought (1902) are the only of his works to include active and repeated euthanasia. When the Sleeper Wakes gives us the adventures of Graham, a late-nineteenthcentury man who falls asleep and wakes two centuries later to find that he is the richest man in the world and that the world's economy is based on his wealth. In the world Graham awakens to, there is a sharp division between rich and poor, charity is outlawed, and euthanasia is "the rich man's refuge from life" (440). A peaceful, painless death is a class issue: "for the poor there is no easy death" (439). Euthanasia might be reserved for the rich, and it is practiced at their behest, but not as a reward. They live a life of wanton pleasure and uselessness and then submit themselves to the "Euthanasy" without ever having children: 
"The world is no place for the bad, the stupid, the enervated. Their duty - it's a fine duty too! - is to die. The death of the failure ... that is the way to improve the race" $(443) .{ }^{6}$ The working class has devolved to a state of physical and mental inferiority, yet they find the spirit to rebel, naming the reluctant Graham as their inspiration. Eventually the working class triumph, but their debilitated state leaves little hope for an ideal society. When the Sleeper Wakes portrays a world in which the upper class has morally degraded, the lower class has physically and mentally degraded, and the competent middle-class is either corrupt or helplessly outnumbered by the worthless. More than his other novels, this is a story of class warfare where over-breeding and degeneration has resulted in a doomed society.

H. G. Wells's Anticipations is, at times, a disturbing look at his social agenda. Neither fiction nor non-fiction, Anticipations can perhaps best be labeled speculative or prophetic a catalogue of events that Wells thinks could or should happen based on the condition of society at the time in which the text was written. This medium restricted Wells, who usually dealt with evolution over the course of thousands of years. Anticipations delves no more than fifty years into the future and thus limited Wells to social Darwinism and the eugenics agenda. Wells was a supporter of social reformist eugenics and was a member of the Voluntary Euthanasia Legalization Society. In Anticipations Wells places the blame for future degeneration on the overly productive birth rate of the lower class, reacting with disgust to the image of "a mean-spirited, under-sized, diseased little man, quite incapable of earning a decent living even for himself, married to some underfed, ignorant, ill-shaped, plain and diseased little woman, and guilty of the lives of ten or twelve ugly ailing children" (306). Wells's solution to this problem? The euthanasia of the weak, silly and useless so the "New Republic" can be run more efficiently by eugenically superior men (307). Wells's definition of unfit is nebulous and disturbing - it seems a person has only to be undersized to be a liability. As ugly as this culling of English undesirables appears, it pales in comparison to Wells's agenda for the "inferior" people of other countries. What, Wells asks, is to be done with

those swarms of black, and brown, and dirty-white, and yellow people, who do not come into the new needs of efficiency? Well, the world is a world, and not a charitable institution, and I take it they have to go. The whole tenor of the world, as I see it, is that they have to go. So far as they fail to develop sane, vigorous, and distinctive personalities for the great world of the future, it is their portion to die out. (342)

Wells never articulates how these people are expected "to die out," but it seems unlikely they would be willing or even able to do it without outside interference.

In many ways Anticipations is a companion piece to When the Sleeper Wakes. In Anticipations, the upper class have become useless and weak and if the lower class is not stopped from over-breeding the competent middle class will be overwhelmed. Thus, in Anticipations, Wells condones an ethical system that checks "the procreation of base and servile types, of fear-driven and cowardly souls, of all that is mean and ugly and bestial" and favors "the procreation of what is fine and efficient in humanity - beautiful and strong bodies, clear and powerful minds, and a growing body of knowledge" (322-23). It is surprising that his harshly-worded screed against the unfit went unremarked at the time and was even mildly endorsed. According to Wells, Anticipations was more successful than most novels (Fate 84) and a 1902 review in the Journal of Political Economy by Caroline Hili praises Wells's 
eugenic ideas, stating that "in view of the predominance of merely conventional views, the possibilities of selectionist morality needs constant exposition" (180). Another reviewer comments slightly on Wells's social agenda, but it is evidently a secondary concern: "The author has not wholly obliterated personal prejudice, but, on the whole, the work gives a suggestive discussion of the probable effects of improvements in transportation, scientific education, and investment" (Annals 120). Even contemporary critics tend to overlook the work's endorsement of euthanasia and eugenics, citing Anticipations as the first of Wells's truly utopian works (Huntington 411). Wells's rather unusual endorsement of machines as an ultimate good tends to be the major focus of both his contemporaries and ours. In 1905 Wells published A Modern Utopia, which in many ways is a fictional retelling of Anticipations. The overall philosophy is the same; the utopia is ruled by elite samurai who decide who qualifies for parenthood based on financial, physical and moral criteria, but the language is less offensive and actual euthanasia is never mentioned. Wells is less angry in this work, but seems unaware that his utopia, built on selective breeding, an oppressive central government, and the constant surveillance of all its citizens, is most people's idea of a dystopia.

Wells may have seen eugenics and euthanasia as possible solutions to the dangers of degeneration, but other authors viewed them as the cause. W. H. Hudson's A Crystal Age (1887), Walter Besant's The Inner House (1888), and E. M. Forster's "The Machine Stops" (1909) use euthanasia to show how humans have become so "civilized" that they are circling around and regressing to a state which is intellectually, morally, and physically inferior. In A Crystal Age, the narrator, Smith, is knocked unconscious by a rockslide and awakens in a distant future when humans live in groups of no more than twenty, and war and violence of all types is unknown. Hudson describes a beautiful utopia with only three serious flaws the lack of romantic love, curiosity, and creativity. All breeding is strictly prohibited except for the "mother" and "father" of the house. Made unhappy by unrequited love and bored by the refined but purposeless life he must lead, Smith takes a potion that supposedly provides a cure for "time and disease" (237). This potion ends up being poison, as euthanasia is now the only relief from a long, boring life. Hudson opens up his novel with a quote from Origins on the biological perfectibility of organic beings, making clear the eugenic agenda that made life in the future so unbearable for Smith. ${ }^{7}$ When all that is "low class" or "bestial" is bred out of man, there is nothing left but a rather vapid shell.

In Walter Besant's The Inner House (1888) the narrator, Dr. Grout, champions euthanasia, but only because a natural death is no longer an option. This story takes place in a not-sodistant future where the discovery of a "Vital Force" stops aging and renders the entire population immortal. In this new society, "There are no individual aims, but all is pure, unadulterated socialism with - not far distant - the Ultimate Triumph of Science" (32). However, without the fear of death and the drive to accomplish something great in their lifetime, the population has become conformist, uncreative, and emotionally deadened. Dr. Linister, leader of a resistance movement against the Vital Force, expressed the importance of death in society: "the gradual extinction of all the emotions - love, jealousy, ambition, rivalry ... made life so poor a thing that painless extinction would be the very best thing possible for the whole race" (153). In this line, it is possible to see the same idea that Wells explored ten years later in When the Sleeper Wakes. In Wells's story, the decadent class chooses a purposeless life, which leads to a desire for death and ultimately the purification of the human race. In The Inner House, the citizens have no choice in the matter, resulting in the stagnation of the human race and, once again, the desire for euthanasia. 
Forster's "The Machine Stops" is, according to the author's "Preface," in direct dialogue with Wells. Forster himself wrote, "The Machine Stops is a reaction to one of the earlier heavens of H. G. Wells" (6). Forster's wording implies that he is reacting to one of Wells's more optimistic future tales, such as A Modern Utopia or perhaps even Anticipation, where technology is a positive. "The Machine Stops" is an unequivocally anti-technology story, and thus is in active disagreement with Wells's later utopias. However, Forster also seems to disagree with Wells on the benefits of euthanasia and eugenic breeding policies, foreseeing such principles as weakening instead of strengthening the race. "The Machine Stops" is set in a future in which all people live underground in individual rooms, communicating through "the speaking apparatus," a very close parallel to contemporary communication through internet message boards and video chat. All aspects of life are provided for by the "Machine," which people have come to worship as a God. There is little to no physical communication between humans. As in Wells's novel, citizens are granted Euthanasia (with a capital E) when they become bored or disenchanted with their lives. However, in Forster's story, euthanasia is not only a way for pampered, over-stimulated citizens to escape their blasé lives, but also a way the Machine keeps humans docile.

By these days it was a detriment to be muscular. Each infant was examined at birth, and all who promised undue strength were destroyed. Humanitarians may protest, but it would have been no true kindness to let an athlete live; he would never have been happy in that state of life to which the Machine called him... man must be adapted to his surroundings, must he not? In the dawn of the world our weak must be exposed on Mount Taygetus, in its twilight our strong will suffer euthanasia.

In an otherwise deadly serious story, Forster inserts some satire, twisting the eugenics argument to show that society now needs weak citizens to progress. He also comments on the importance of euthanasia in human evolution, the exposing of the weak in early civilizations, and then devolution, which eventually results in the Machine breaking down and, as there is no one to fix it, the obliteration of humankind. This devolution is blamed directly on the eugenic and evolutionary ideas that have come to dominate society, as well as the exchange of personal freedoms and human contact for self-reliance and civic duty. As humans are being literally crushed by the collapsing Machine, the narrator names physical and mental regression as the root cause of the destruction of man: "The sin against the body - it was for that they wept in chief; the centuries of wrong against the muscles and the nerves, and those five portals by which we can alone apprehend - glozing it over with talk of evolution, until the body was white pap, the home of ideas as colourless, last sloshy stirrings of a spirit that had grasped the stars" (22).

All of Forster's novels center on the importance of and the journey toward human connection, an idea that is the cornerstone of the Humanist movement that was so important to Forster. "The Machine Stops" is no different. The story is less a commentary on technology and more a warning of how humans can become easily alienated from each other. To Forster class was the greatest obstacle toward true human connection (as explored in-depth in Passage to India) and this is the driving force behind "The Machine Stops" and its antieugenic argument. The majority of Victorian speculative fiction used eugenics and euthanasia to strengthen the middle-class while eliminating the lower and upper classes, which were viewed as parasitic. "The Machine Stops" is speaking against such class politics and looking 
forward to the speculative fiction of the mid-twentieth century, such as Brave New World (1931), where a selective breeding policy is a dystopian attribute.

A Crystal Age, The Inner House, and "The Machine Stops" are all works that point out flaws in eugenics by presenting societies in which all social differences have been eliminated. Unlike the paradises depicted in works such as News from Nowhere and Looking Backward, total social equality does not result in a happy and intellectually stimulated society, but rather in colorless worlds where individuality has been drummed out in favor of bland conformity. These works speculate that that lower class has something to offer society, a warmth and humanity that is lacking in the civility of the middle class. Euthanasia is used as a way to regulate citizens, but more importantly, it offers an escape from lives so pointless they are no longer worth living. This is particularly poignant when viewed against the rhetoric that presented euthanasia as a humane alternative to the miseries of real life. All three authors present worlds where perhaps naïve heroes would welcome physical deprivation as a release from the numbness of a totally sheltered life.

While Grant Allen's "The Child of the Phalanstery" (1884) is a simpler story than any discussed so far, what the author hoped to convey through the story is more problematic. Set in a utopian socialist society in which citizens are taught to "think least and last of" their own feelings and "first and foremost of the progressive evolution of universal humanity" (302), "The Child of the Phalanstery" reads like a nineteenth-century Twilight Zone episode. Two young people, Olive and Clarence, wish to marry and have children, despite Olive's "slight feebleness in constitution" (305). This is no small matter, as the council that rules the phalanstery, headed by a man who resembles Charles Darwin in both appearance and disposition, views as "wrong and immoral...marriage with a person in ill-health, or of inferior mental power, or with a distinctly bad or insubordinate temper ... or a first cousin" (305). However, the kindly hierarch, perhaps blinded by his paternal love for Olive, lets the couple marry. The error of this is seen when Olive gives birth to a child "that the phalanstery must not for its own sake permit to live" (308), a girl with its feet turned inward. The hierarch laments this necessity, but a fellow council member, more rational than his emotional leader, sees good in this regrettable death, as, he explains, it tries "our fortitude, our devotion to principles, our obedience to the highest and the hardest law" (308). In the phalanstery, the death of an undesirable is a teachable moment. The baby is chloroformed on "Darwin, December 20" (317), and Olive, who holds the baby in her arms, drops dead of shock.

A cursory reading of this story would lead a modern reader to believe that Allen was warning against the dangers and cruelty of such eugenic thinking. How could he be condoning the death of little "sweet pet" (as Olive names her child - a rather dehumanizing nomenclature) and the death of gentle Olive? However, the text suggests that the wrong in this story is not the euthanasia of Olive's child, but in the weakness that allowed Olive and Clarence to marry in the first place. Olive herself questions whether she is strong enough to have children, but her objections are overborne by the love Clarence and the hierarch bear for her, even though the hierarch knows Olive is better fitted for a life as a "celibate sister," taking care of children and the sick (304). The tragedy starts here, when love is allowed to triumph over what is best for Olive and for the community.

At no point does anyone, not even Olive or Clarence, question the need to euthanize the child. Clarence, who is sympathetic throughout the story, gives voice to how such deaths should be viewed: "I don't feel it for the baby's sake: for her 'tis better so: she will be freed from a life of misery and dependence; but for my own" (309-10). Clarence must conquer his 
weakness to serve the interests of his child. Indeed, by displaying sorrow and the wish it were otherwise, characters such as the nurse, who is so touched by Olive's "attempted resignation" that she is almost "tempted to wish she had been born in the old wicked prephalansteric days" (312), are showing that their humanity is expanded rather than deflated by the harsh rules of their society. Even Olive's own mild rebellion in feeling she "would rather be a miserable naked savage... if only she could keep that one little angel of a crippled baby" (314) shows that life at the phalanstery leaves women with their maternal instincts intact. Even Olive's death, proof that she was physically and mentally unfit to be a mother, is a testament to the kindness and sacrifices of the people of the phalanstery: "No sister on earth could wish to die more nobly than by thus sacrificing her own life and her own weak human affections on the altar of humanity for the sake of her child and of the world at large" (319-20). Olive has become a martyr for the philosophy of the phalanstery. "The Child of the phalanstery" is a love letter to civic duty, self-sacrifice, and self-reliance.

Grant Allen's history confirms a pro-eugenics reading of "The Child of the Phalanstery." Allen was a biologist, a socialist, and a supporter of Charles Darwin and Herbert Spencer, all characteristics that defined nineteenth-century followers of eugenics. He is popularly known for his controversial novel The Woman Who Did (1895), the educated heroine of which is a eugenics feminist. According to Richardson, Grant Allen was the leading exponent of a "biological narrative" that "was shaping the debates on poverty and the role of women in society ... [by] equating the ugly with disease and the beautiful with health" (80). According to Allen, "The ugly for every kind, in its own eyes, must always be (in the main) the deformed, the aberrant, the weakly, the unnatural, the impotent. The beautiful for every kind must similarly be (in the main) the healthy, the normal, the strong, the perfect, and the parentally sound" (81). Allen did not believe, like New Woman writer Sarah Grand, that passion was "anathema to responsible marriage" (qtd. in Richardson 113). Instead, as Allen argues in his essay "Falling in Love," love and romance is "a mere lateral form of natural selection - a survival of the fittest in the guise of mutual attractiveness." Essentially, passion will lead women to choose their perfect eugenic match. Sexual selection and survival of the fittest ensure that beautiful people will eventually only mate with other beautiful people, eventually outnumbering the unfit. "The Child of the Phalanstery" is the story of the bumpy road to this perfect society. While his eugenic agenda might make modern readers cringe, he was considered progressive during his time. Morton views this story as nothing but criticism of the Galtonian eugenics of which Allen disapproved of, but that reading does not take into account the parts of the story that support Allen's own social reform eugenics agenda, which saw sexual selection, not natural selection, as the best and speediest way to bring about a eugenic worldview. ${ }^{8}$ Allen's main idea was that it was the responsibility of women to choose the best mate or, if the women are not made up of the best genetic material, to absent themselves from the marriage market. "The Child of the Phalanstery" is ultimately about the weakness of a woman who did not do what she knew was right and instead caused pain and suffering for her whole community. To the extent that the story is critical of eugenics, it is critical only of forced eugenic polices, an idea that went strongly against Allen's socialist world view. In a perfect society, according to Allen, people would always make the correct choice without any governmental pressure.

A pro-eugenics reading brings to light the artistry of this story, which otherwise appears a ham-fisted cautionary tale. At all times, the characters - even the ones lobbying for the death of the child - are understandable and relatable. They all seem genuinely interested in 
the happiness of the child and society as a whole and seem to care very little for their own contentment. They are also reassuringly human. Most utopian tales suffer from characters that have evolved so far past man's current state that they are alien, such as the Vril-ya in The Coming Race, or inhumanly cruel, such as the upper class in When the Sleeper Wakes. Allen's characters, one and all, are responsible citizens who put the needs of the whole before the wants of the few, thus providing for the strength and happiness of the "men of the future" they are breeding. It is social Darwinism and eugenics at its most persuasive and, perhaps, seductive.

Indeed, this seductiveness is the distinctive contribution fiction makes to the euthanasia debate. At its core euthanasia was an abstract concept in the nineteenth century. It was certainly practiced, but on an individual scale - it was always private and always concealed. By putting a face on its practitioners, by providing a particular situation and setting that benefits or loses by its practice, fiction made an abstract concept as real as possible. Novels made and continue to make euthanasia both more and less palatable. Speculative fiction was manufacturing evidence, both in defense of and against euthanasia, showing the reading public how this social agenda would play out in the "real" world. It did not matter if the evidence was real - it was something solid that could be pointed to as proof.

\section{The Fixed Period}

Anthony Trollope's THE FIXED PERIOD (1881-82) is influenced by both Darwinism and social Darwinism, presenting a future society that thrives on the idea of compulsory euthanasia at the age of sixty-eight, if not the practice. This novel is the perfect focal point for my study as, I argue, the euthanasia practiced is a direct result of Malthusian ideas that attacked the elderly and Darwinian-influenced theories that predicted that man was moving toward a more perfect state, ideas picked up on and spread by eugenic thinkers. This novel also shows the influence of Williams's essay, with the main character parroting many of Williams's points about man's duty to put the chronically ill out of misery. The Fixed Period is a reaction to theories and policies practiced throughout the nineteenth century that contributed to the acceptance of euthanasia as part of Britain's future. Trollope, who was only one year away from the Fixed Period when he wrote the novel, produced a work that is of its time despite being set a hundred years in the future.

The novel, however, is problematic in that it is not clear what Trollope's real feelings on euthanasia are. Civic duty taken too far and misplaced compassion seem to be his targets, but this easy analysis is complicated by Trollope's refusal to fully vilify Mr. Neverbend, Britannula's president and the driving force behind the Fixed Period, or the Fixed Period itself. Trollope is both satirizing the concept while showing the real-life benefits of such a program. Further, he seems to have real sympathy for a fledgling nation and its leader fighting against the imperialism of Britain. In this way The Fixed Period is more than a microcosm and instead is an example of the confusing and often conflicting emotions people had about personal liberty and the Victorian values of self-reliance and civic duty. How far is too far and who has the right to make that decision? In this novel, in a way not available in non-fiction, the reader is given a glimpse into the morally ambiguous and conflicting mind of the British public.

Set in 1980, The Fixed Period takes place in Britannula, a former British colony, now independent. Written in first person (the only one of Trollope's novels so written) from 
the perspective of Neverbend, the novel is Neverbend's memoires of his efforts to enforce the Fixed Period - the mandatory euthanasia of all residents at the age of sixty-eight. This law was introduced by Neverbend, but was fully accepted and voted on by the country's parliamentary system. However, at the time of the vote, Britannula was made up of young men. When the time comes for the first person to be "deposited" in a "college" so he can prepare for his death, discontent over the law spreads. The action of the novel centers on Neverbend's efforts to get Crasweller, the first citizen to turn sixty-eight and Neverbend's best friend, to accede to the Fixed Period. Neverbend fails, and eventually Britain takes away Britannula's independence and permanently banishes Neverbend from his country. Despite what might be viewed as a rather ghastly agenda, Neverbend is never vilified. He is lightly mocked and is the object of satire, but he is a sympathetic and fully realized character overall. However, it is likely that this sympathy on the part of the reader might not be sustainable if Neverbend had been able to successfully euthanize the healthy and vigorous, if elderly, Crasweller.

Although The Fixed Period has attracted much less critical attention than any of Trollope's other works - it is widely considered a failure as both novel and social commentary - it is striking that the small body of work it has accumulated does not contain a single analysis of euthanasia qua euthanasia. ${ }^{9}$ I believe that euthanasia in the novel is a response to the actual idea of euthanasia, and a critique of the social practices throughout the century that made such thinking a vital part of the future. Indeed, we can see The Fixed Period as a delayed reaction to the New Poor Law, which seriously imperiled the working-class poor. Savings was almost nonexistent among this class, and once laborers were no longer able to work, it was expected that their families would take care of them, an assumption that few elderly could count on. According to Claudia Nelson in her study of the Victorian family, there were two schools of thought on the subject - the expectation by the middle class that the lower class would take care of its own, and the too frequent reality that "the well-being of the younger generations trumped the needs of older people, especially when the latter were aunts or uncles rather than parents" (129). One is reminded of old Nandy from Dickens's Little Dorrit (1855-57), who voluntarily enters the workhouse so he won't be a drain on his daughter. Many older people had no family support, and Victorian England provided very little in the way of a safety net. ${ }^{10}$ With the passage of the 1834 New Poor Law, all outdoor relief for the elderly was cut off, except for those privileged few who were already receiving assistance from their families. The rest could either enter the workhouses or starve. While Victorian literature focused on the children of the workhouse, the reality is that the elderly made up the largest single group of workhouse residents. By 1890, one-third of the average workhouse population was made up of the elderly, with this figure being demonstrably higher in London and other cities (Nelson 130). Considering the short life span of the lower classes, the average age of the "not well-to-do" in 1888 was only 28.8, the number of elderly in workhouses was proportionally enormous (Smith 316-17).

The workhouse carried a strong stigma, especially for the elderly, who were made to feel they should have somehow prepared for their old age or been supported by their families. Life in a workhouse was humiliating and harsh. Laws throughout the century made the conditions of the indigent elderly even worse, such as a series of laws in the 1870s that cut off less stigmatized types of government assistance for elderly women and almost eliminated pensions altogether (Nelson 131). The situation for the elderly was such a social problem that, in the late 1880 s, social researcher Charles Booth began to lobby for the establishment 
of a state-funded pension for the elderly, a project that was finally realized in 1908. This atmosphere of hostility and contempt directed toward the indigent elderly was the backdrop to The Fixed Period. Add to this Trollope's own dread of approaching old age and his fear that he would no longer be able to support himself, and his indignation against those who viewed the elderly as expendable is clear. Even the elderly who were financially secure had to deal with a certain amount of social stigma. Numerous nineteenth-century personal letters, journals, and novels expressed the wish that the suffering elderly, usually under the thrall of a painful disease, would be given a peaceful death, with compassion and social stigma being the most cited justification.

Neverbend's compassion is perhaps the most unsettling element of The Fixed Period. After viewing the lot of the elderly - how they are viewed as useless, how they are seen as a burden on society, and how they suffer from both physical pain and shame - he concludes that they would be better off dead and actively works to have them euthanized - out of compassion. In the quote below Neverbend argues persuasively for the humanitarian goals of the Fixed Period, that it will rescue the elderly from the two greatest indignities of old age: imbecility and poverty.

\footnotetext{
[The Fixed Period] consists altogether of the abolition of the miseries, weakness, and fainéant imbecility of old age, by the prearranged ceasing of life of those who would otherwise become old. Need I explain to the inhabitants of England, for whom I chiefly write, how extreme are those sufferings, and how great the costliness of that old age which is unable in any degree to supply its own wants? Such old age should not, we Britannulists maintain, be allowed to be. This should be prevented, in the interest both of the young and of those who do become old when obliged to linger on after their 'period' of work is over... they would depart with the full respect of all their fellow-citizens. To how many does that lot now fall? During the last years of their life they were to be saved from any of the horrors of poverty ... to them there would be no degraded feeling that they were the recipients of charity. (5-6; vol. 1, ch. 9)
}

Neverbend's argument calls attention to the lack of respect and support accorded to the elderly in England (it seems Neverbend's 1980 is much the same as Trollope's 1880) and the general indignity of getting older. And Neverbend is not merely giving lip service to the compassionate side of his argument - it is obvious throughout the book that he truly feels for the elderly and has nothing personal to gain from their demise. He stresses numerous times that "the Fixed Period had been carried chiefly with a view to relieving the miseries of the old" (31; vol. 1, ch IV) and has nothing but disdain for Crasweller's future son-in-law who supports the law only so he can sooner inherit Crasweller's fortune. Indeed, Neverbend accuses all who are against the Fixed Period of "fiendish cruelty" (31; vol. 1, ch. IV), perhaps reminding Victorian readers of the popular essay by eugenicist W. R. Greg, who, naming the people he views as a drain on society, argues that "a truly kind nature would want to see [them] extinguished" (qtd. in Morton 123). Neverbend is a product of his environment and a practical, compassionate man. He is, Trollope suggests, the kind of man we will have a hundred years from now if the politics and attitudes of the present continue.

The interweaving of social responsibility and compassion is a key component of the Fixed Period, making it a true Malthusian edict. As illustrated in the quotation above, Neverbend and the other proponents of the Fixed Period are unable, even when speaking of the benefits to the elderly, to avoid mention of the great financial benefits such a plan will yield for their 
fledgling country. Indeed, much of Neverbend's rhetoric sounds as if it were taken directly from Malthus's An Essay. According to Neverbend, the first of the two great mistakes made by man is in "allowing the world to be burdened with the continued maintenance of those whose cares should have been made to cease" (6; vol. 1 , ch. I). He then goes on to map out scientifically the drain of the elderly on the general population and calculate the benefits of their removal:

\begin{abstract}
Statistics have told us that the sufficient sustenance of an old man is more costly than the feeding of a young one ... we should save on an average $£ 50$ for each man and woman who had departed. When our population should have been a million, presuming that one only in fifty would have reached the desired age, the sum actually saved to the colony would amount to $£ 1,000,000$ a-year. It would keep us out of debt, make for us our railways, render all our rivers navigable, construct our bridges, and leave us shortly the richest people on God's earth! And this would be effected by a measure doing more good to the aged than to any other class of the community! (6-7; vol. 1, ch. I).
\end{abstract}

This measuring of money and naming of benefits mirrors the language used by Malthus and later neo-Malthusians when lobbying for the recantation of all aid to the needy, which I view as an early form of passive euthanasia. While Malthus does not say as much about the destitute elderly as he does the young, he certainly implies that they are a burden to the state. When speaking of a Chinese law that requires the young to take care of their parents, Malthus writes that "he would not pretend to determine" if such a law would be advisable in England, "but it seems at any rate highly improper, by positive institutions, which render dependent poverty so general, to weaken that disgrace, which for the best and most humane reasons ought to attach to it" (28). As Malthusian theory was instrumental in drafting the New Poor Law, with its rough treatment of the indigent elderly, it seems that many agreed with Malthus that disgrace was the lot of such dependence. Neverbend's philosophy is merely the next step in Malthusian theory. Considering that Malthus supported the active starvation of unwanted children, Neverbend's plan for the elderly seems humane in comparison.

Neverbend's arguments repeatedly mirror Williams's claim about the hypocrisy of "the sacredness of life" argument, making it likely that Trollope read and was influenced by the pioneering euthanasia essay. Williams posits that arguments against euthanasia based on "the sacredness of life" are disingenuous, as this concern "is thrown to the winds, the moment national or political passion grows hot, or even when mere material interests are seriously threatened" (215). Neverbend makes the same argument, noting that Britannula has "freed [itself] from the stain of capital punishment" (46; vol. I, ch. V) and is bitter and incredulous that Britain is willing to kill thousands (with the 250-ton gun they have aimed at Britannula) merely to keep one old man from being euthanized. If death is in the hands of the Almighty, Neverbend asks, "why is all Europe bristling at this moment with arms prepared, as we must suppose, for shortening life - and why is there a hangman attached to the throne of Great Britain as one of its necessary executive officers ... there is a prejudice about killing an old man, or a woman. Young men don't matter" (102, 119; vol. II, ch. XII). In these passages Trollope treats Neverbend with respect and dignity; his adversaries have no rebuttal and look simple and foolish. While Neverbend is often a subject of satire, he is just as often the voice of reason.

While social Darwinism and the questionable kindness that accompanies such thinking is the driving force behind the Fixed Period, eugenics also plays a small role. According to 
Neverbend, Britannula is made up of "the very cream, as it were, that had been skimmed from the milk-pail of the people of the wider colony, themselves gifted with more than ordinary intelligence. We were the élite" (12; vol. I, ch. II). This obvious selection of the best specimens for relocation in Britannula smacks of Galtonian eugenics, as does the obliteration of disease and weakness through the euthanasia of the elderly. While Galton never supports euthanasia, his utopian novel Kantsaywhere does champion the forced segregation and chastity of all undesirables. Euthanasia is the next radical step. Trollope also parallels the superiority of the people of Britannula with the superiority of their livestock, "a small flock of choice animals" who are selectively bred and "give nothing but cream" (12; vol. I, ch. II). The repeated use of "cream" connects the breeding of elite people with the breeding of elite animals, making Britannula a eugenic utopia.

Trollope's comment about The Fixed Period to a Blackwood's Magazine reviewer that "it's all true - I mean every word of it" (Collins 577) complicates an already complicated text. Neverbend is defeated and the Fixed Period is overturned, not through logic and empirical proof, but through force. Considering Trollope's anti-imperialist views, it is difficult to believe that he did not feel some sympathy for the fledgling nation of Britannula. Neverbend wins every argument he has on the Fixed Period, and even those most opposed to it are not against the actual law but against how it will affect them. Crasweller's daughter, who is instrumental in summoning the British to overturn the Fixed Period, is not completely opposed to the law: "You ought to begin with some weak, crotchety, poor old cripple, who would be a great deal better out of the way" (34; vol. I, ch. IV). Even Crasweller is not against the Fixed Period; he feels it is fine for those who are infirm (22; vol. I, ch. III). I am not suggesting that Trollope truly supported the forced euthanasia of the elderly, but he was responding to a social climate that implied that the elderly were a needless drain on society and to a philosophical debate that actually stated that those who suffer should be put out of their misery. Trollope was fast approaching the Fixed Period when he wrote the novel, and I believe both the novel and his comment to the Blackwood's reviewer show a man who was bitter about the loss of status he felt he suffered though aging and fears about his future. His novel shows the influence of Malthus, the New Poor Law, eugenics, and active euthanasia. The Fixed Period is a mélange of all philosophies of the period that, for whatever motive, supported the idea that some people were better off dead. Neverbend may have been defeated, but he is secure in the idea that the Fixed Period will survive and be picked up by a future generation (19; vol. I, ch. II). That is the feeling, if not the hope, of all authors of speculative fiction that deals in euthanasia, both at the end of the nineteenth century and the beginning of the twenty-first.

\section{University of Georgia}

\section{NOTES}

1. Pointing out the Darwinian-influenced language and philosophy of these ideas is not revelatory by itself. Almost all facets of life were influenced in some way by the language, if not the actual theories, of Charles Darwin. What I focus on is the intersection between euthanasia and Darwinian thought, which found a home in late-Victorian future fiction. It would be no exaggeration to say that the majority of, if not all, nineteenth-century future fiction was influenced by Darwinism, and that the preponderance of such fiction included some form of euthanasia. I will not be defending or even trying to pick out the 
strains of the different theories that fell under the umbrella of Darwinism in the mid- to late-nineteenth century; that is well outside the scope of this study and would require many volumes. For my purposes, it is merely enough to demonstrate the influences of Darwinism on speculative fiction and how they connect to euthanasia.

2. For more on the argument of "quality of life" versus "a social judgment about a person's comparative worth," see Emanuel's The Ends of Human Life: Medical Ethics in a Liberal Polity.

3. See Jalland's Death in the Victorian Family for a full discussion of what makes a "good" death.

4. This is a simplification of the issue, which, like Darwinism, had many warring branches. There were as many different theories of eugenics as there were thinkers to put their unique spin on them. However, all branches, to an extent, fell into the camps of either negative or positive.

5. Hair was often used to show a human's primitive state. Victorian social scientists who wished to prove the moral superiority of women would cite their hairless bodies, and in E. M. Forster's dystopic short story "The Machine Stops" (discussed later), a character is satirically described as "savage" because he is growing a mustache. However, it is amusing to note that it is the heroes hairy body in The Coming Race that in part attracts the female Virl-ya.

6. Euthanasia at the end of a life devoted to nothing but pleasure became a theme of dystopic literature after this novel, with Aldous Huxley's Brave New World (1932) as the most popular and enduring example.

7. For a full analysis of the Darwinian elements of A Crystal Age, see chapter three of Morton's The Vital Science.

8. See Morton 135-43, for his reading.

9. Even though compulsory euthanasia of all people at the age of sixty-eight is the key component and main plot point of The Fixed Period, the small number of critics who have analyzed the novel do not focus on that facet. Instead, euthanasia is often relegated to the sidelines, and when it is addressed, it is usually as a metaphor or symbol. Alessio views The Fixed Period as part of the New Zealand utopia tradition, with the one million pounds a year Britannula will save through the Fixed Period mirroring the New Zealand debt of the time (76). Blythe also argues that Trollope is addressing an international issue, namely the "human sacrifice" of the Maori and other colonized peoples in the Empire (2). In her study of Victorians and old age, Chase examines the debate around cremation to which Trollope is responding. Cockshut looks at The Fixed Period only to better understand Trollope's view of death, ultimately concluding that the novel is a failure in that regard (91), while Hadomi views the novel as a "metaphoric presentation" of the desire to overcome mortality (86). apRoberts uses the novel to "display and define" the Trollopian unit of structure (46), and Kincaid analyzes it as a dramatic monologue (244-48). Nardin, in both of her studies of the novel, uses The Fixed Period to show Trollope's originality as a political thinker, drawing on Neverbend's character to analyze the rationalist social critic in one article and the utilitarian reformer in the second. Nardin discounts the idea that the novel is about death at all (164), viewing it as a long character study. Indeed, Neverbend as a character has attracted far more critical attention than any other facet of the novel. Shirley Robin Letwin focuses on the folly of Neverbend's "humanitarian blueprint" (179), while Skilton views Neverbend as "another of Trollope's many studies of fanaticism or idée fixe" (3). Rogers views The Fixed Period as Trollope's "A Modest Proposal," with Neverbend playing an "anti-Cicero" part (18), and Robert Tracy argues that the novel is about the problem of "abstract reformers" (287).

10. See chapter five of Nelson's Family Ties in Victorian England for examples of the repercussions for working-class families who did take in their elderly.

\section{WORKS CITED}

Alessio, Dominic. “A Conservative Utopia? Anthony Trollope's 'The Fixed Period'.” Journal of New Zealand Literature 22 (2004): 73-94. 
Allen, Grant. "The Child of the Phalanstery." Strange Stories. London: Chatto \& Windus, Piccadilly, 1884. 301-20.

Appleman, Phillip. "Darwin: On Changing the Mind." Darwin: A Norton Critical Edition. 2nd Ed. Ed. Philip Appleman. New York: W. W. Norton, 1979.

apRoberts, Ruth. Trollope: Artist and Moralist. London: Chatto \& Windus, 1971.

Barker, David. "How to Curb the Fertility of the Unfit: The Feeble-Minded in Edwardian Britain." Oxford Review of Education 9.3 (1983): 197-211.

Besant, Walter. The Inner House. London: Arrowsmith, 1888.

Blythe, Helen Lucy. "The Fixed Period (1882): Euthanasia, Cannibalism, and Colonial Extinction in Trollope's Antipodes." Nineteenth-Century Contexts 25.2 (2002): 161-80.

Bulwer-Lytton, Edward. The Coming Race. Ontario: Broadview, 2008.

C.C.C. Rev. of Anticipations of the Reaction of Mechanical and Scientific Progress Upon Human Life and Thought by H. G. Wells. Journal of Political Economy 11.1 (Dec., 1902): 177-80.

Chase, Karen. The Victorians and Old Age. London: Oxford UP, 2009.

Cockshut, A. O. J. Anthony Trollope: A Critical Study. New York: New York UP, 1968.

Collins, W. L. "Autobiography of Anthony Trollope." Blackwood's Magazine 134 (Nov. 1883): 57790.

Dickens Charles. The Life and Adventures of Martin Chuzzlewit. Boston: Lee and Shepard, 1877.

Emanuel, Ezekiel J. The Ends of Human Life: Medical Ethics in a Liberal Polity. Boston: Harvard UP, 1991.

Forster, E. M. Collected Short Stories. Harmondworth: Penguin, 1954.

Ghent, J. Our Benevolent Feudalism. New York: MacMillan, 1902.

Grant, Allen. Falling in Love: With Other Essays on More Exact Branches of Science. London: Smith and Elder, 1889.

Greg, W. R. "On the Failure of 'Natural Selection' in the Case of Man." Fraser's Magazine 78 (1868).

Hadomi, Leah. "Islands of the Living: Death and Dying in Utopian Fiction." Utopian Studies 6.1 (1995): 85-101.

Hili, Caroline M. Rev. of Anticipations of the Reaction of Mechanical and Scientific Progress Upon Human Life and Thought by H. G. Wells. Annals of the American Academy of Political and Social Science 20 (Sept. 1902): 120.

Hudson, W. H. Works of W.H. Hudson: A Crystal Age. London: J.M. Dent \& Sons, 1922.

Huntington, John. "H. G. Wells: Problems of an Amorous Utopian." English Literature in Translation, 1880-1920 30.4 (1987): 411-22.

Jalland, Pat. Death in the Victorian Family. Oxford: Oxford UP, 1996.

Kemp, N. D. A. "Merciful Release" The History of the British Euthanasia Movement. Manchester: Manchester UP, 2002.

Kincaid, James R. The Novels of Anthony Trollope. Oxford: Clarendon, 1977.

Knott, John. Popular Opposition to the 1834 Poor Law. New York, St. Martin's, 1986.

Letwin, Shirley Robin. The Gentleman in Trollope: Individuality and Moral Conduct. Cambridge: Harvard UP, 1982.

Malthus, Thomas Robert. An Essay on the Principle of Population. Ed. Philip Appleman. New York: Norton, 1976.

Morris, William. News From Nowhere. New York: Oxford UP, 2009.

. The Wood Beyond the World. Boston: The Roberts House, 1895.

Morton, Peter. The Vital Science: Biology and the Literary Imagination, 1860-1900. London: Allen and Unwin, 1984.

Nardin, Jane. Trollope \& Victorian Moral Philosophy. Athens: Ohio UP, 1996.

Nelson, Claudia. Family Ties in Victorian England. Westport: Praeger, 2007.

Richardson, Angelique. Love and Eugenics in the Late Nineteenth Century: Rational Reproduction and the New Woman. Oxford: Oxford UP, 2003.

Rogers, Henry N. “The Fixed Period: Trollope's 'Modest Proposal.”' Utopian Studies 10.2(1999):16-24. 
Skilton, David. “The Fixed Period: Anthony Trollope's Novel of 1980." Studies in the Literary Imagination 6.2 (Fall 1973): 39-50.

Smith, F. B. The People's Health 1830-1910. New York: Weidenfeld \& Nicolson, 1990.

Stevenson, Lionel. Darwin Among the Poets. New York: Russell \& Russell, 1963.

Tracy, Robert. Trollope's Later Novels. Berkley: U of California P, 1978.

Trollope, Anthony. The Fixed Period. New York: Echo Library, 2010.

Wells, H. G. Anticipations of the Reactions of Mechanical and Scientific Progress upon Human Life and Thought. London: Nabu, 2010.

-. The Fate of Homo Sapiens. London: Secker \& Warburg, 1939.

. "When the Sleeper Wakes." The Collector's Book of Science Fiction by H. G. Wells. Ed.Alan K. Russell. New Jersey: Castle, 1978.

Williams, Samuel D. "Euthanasia." Essays by Members of the Birmingham Speculative Club.London: Williams and Norgate, 1870. 